\title{
Community Compliance with the Covid-19 Protocol Hygiene Policy in Klaten Regency, Indonesia
}

\author{
Hari Sutra Disemadi ${ }^{1 *}$, Denis Oxy Handika ${ }^{2}$
}

\footnotetext{
${ }^{1}$ Faculty of Law, Universitas Internasional Batam, Riau, 29442, Indonesia

${ }^{2}$ Faculty of Public Health, Diponegoro University, Semarang, Central Java, 50275, Indonesia

* Corresponding author: haridisemadi@gmail.com
}

\begin{tabular}{|c|c|}
\hline Article & Abstract \\
\hline $\begin{array}{l}\text { Article History } \\
\text { Received: Mei 11, 2020; } \\
\text { Reviewed: June 5, 2020; } \\
\text { Accepted: July 28, 2020; } \\
\text { Published: Sept 30, } 2020 .\end{array}$ & $\begin{array}{l}\text { The problem for all countries in the world, including Indonesia, is the presence of } \\
\text { a virus originating from Wuhan City, China. This virus is known as COVID- } \\
\text { 19. The Government of Indonesia has established COVID-19 as a type of disease } \\
\text { that causes a Public Health Emergency. Therefore, prevention efforts must be made } \\
\text { in accordance with existing provisions. The research method used is a socio-legal } \\
\text { research method with a normative legal approach and a sociological approach } \\
\text { conducted in Klaten-Central Java. The results of this study indicate that the policy } \\
\text { currently being taken is health quarantine. The policy is the issuance of health } \\
\text { protocols for the community. This protocol is known as the COVID-19 hygiene } \\
\text { protocol, one of which is related to the obligation to wear masks by everyone when } \\
\text { outside the home and the Hand Washing with Soap (CPTS) movement with } \\
\text { running water either/ both the use of antiseptic hand sanitizers as stipulated in the } \\
\text { Ministry of Health Circular Number HK.O2.02/I/385/2020. The level of } \\
\text { awareness and compliance in Klaten Regency on the policy is exceptionally well, } \\
\text { indicated by the dominant number of people in the use of masks when they are } \\
\text { outside of the house and washing their hands with soap with running water } \\
\text { either/ both using antiseptic hand sanitizers. Therefore, the existence of a health } \\
\text { protocol as a government policy in accelerating COVID-19 countermeasures is } \\
\text { expected by parties, such as the Regional Government and the community in } \\
\text { playing an active role referring to those who are feverish to the nearest hospital. } \\
\text { Then, the Regional Government can socialize or urge people to use masks. For } \\
\text { emergencies, if you sneeze or cough in a public area, cover your mouth with your } \\
\text { inner elbows or upper sleeve. People who are sick are also advised not to use public } \\
\text { transportation to minimize the possible riske of spreading the disease. }\end{array}$ \\
\hline
\end{tabular}

(C)2020; This is an Open Acces Research distributed under the term of the Creative Commons Attribution Licencee (https://Creativecommons.org/licences/by/4.0), which permits unrestricted use, distribution, and reproduction in any medium, provided the original works is properly cited. 


\section{INTRODUCTION}

Coronavirus Disease 2019 or better known as COVID-19 is a virus that originates from non-humans transmitted to humans (Bashir et al., 2020; Chen et al., 2020; Shereen, Khan, Kazmi, Bashir, \& Siddique, 2020; Xie \& Chen, 2020; Xu et al., 2020). Disease caused by this virus is an infection that is very contagious and causes acute respiratory syndromes that can be deadly. COVID-19 first discovered from Wuhan-China at the end of 2019 (Chakraborty \& Maity, 2020; Dantas, Siciliano, França, da Silva, \& Arbilla, 2020; Shereen et al., 2020).

The transmission pattern of COVID-19 is from "human to human" (Bashir et al., 2020; Shereen et al., 2020), to cause the spread of COVID-19 transmission so quickly that it reaches all parts of the world including Indonesia. At present, due to the spread level, severity, and inaction of COVID-19 countermeasures, the World Health Organization (WHO) categorizes COVID-19 as a pandemic (World Health Organization, 2020). The situation related to the transmission of COVID-19 in Indonesia as of May 5, 2020, 12,071 people were positive for COVID-19 with 872 cases of death. While the number of people with observation (ODP) was 239,226 people, and 26,408 patients in monitoring (PDP) (Kementrian Kesehatan Republik Indonesia, 2020).

The speed and scope of virus transmission are highly rapid, urging the Government of Indonesia and related parties to establish policies to overcome COVID-19 spread (Barkur, Vibha, \& Kamath, 2020; Hidayatullah, 2016; Lupia et al., 2020). The fast and precise policy establishment is believed to play a significant role in tackling the effects of COVID-19 transmission, which until now no vaccine nor medication has found yet. If COVID-19 spread cannot be dealt with as soon as possible, the impact of the virus transmission may affect and disturb the crucial joints of a country such as health, economics, education, politics, law, defense, and even religion (Ina Ola, Huda, \& Putera, 2018).

Considering that COVID-19 transmission is highly 'Massive', there are many techniques used by the Indonesian government in handling this massive transmisiion. One of them is controlling the mobility (activities) of the community, especially people infected with COVID-19 (Syah, 2020). The technique currently used to control the transmission of COVID-19 is the control of territorial and transportation rush both air, sea, and land (Al-Fatih, Ahsany, \& Alamsyah, 2020).

Several countries in the world have carried out preventive action with the existence of a regional quarantine policy (lockdown), including Indonesia has carried out preventive prevention of transmission of COVID-19 by issuing a regional health quarantine policy in certain regions (Barkur et al., 2020; Dantas et al., 2020; Yunus \& 
Rezki, 2020). The health quarantine is temporary, which is only during the mitigation of COVID-19 transmission that quite low and stable (Yunus, 2020). In Indonesia, the health quarantine policy is regulated under the Government Regulation No. 21 of 2020 concerning Large-Scale Social Restrictions in the Context of Accelerating the Handling of Corona Virus Disease 2019 (COVID-19).

Large-scale Social Restrictions (PSBB) has been instructed in several regions in Indonesia, which are in DKI Jakarta and West Java Province. The government under the PSBB policy is more encouraging people to do social distancing and physical distancing, namely restrictions on community activities outside the house. Companies throughout Indonesia are also encouraged to implement the Work From Home (WFH) policy as an attempt to prevent transmission of COVID-19. In addition to policies related to health quarantine through PSBB, the Government of Indonesia has also implemented several COVID-19 protocol hygiene policies as a preventive tactic to prevent COVID-19 transmission.

One of the COVID-19 protocol hygiene policies in forestalling the spread of the virus is one of which is the use of masks by everyone when outside the home and the Hand Washing with Soap (Cuci Tangan Pakai Sabun/CTPS) movement with running water either/both antiseptic hand sanitizer. This policy is regulated under the Ministry of Health Circular No. HK.02.02/I/385/2020 concerning the Use of Masks and the Provision of Hand Washing with Soap (CTPS) Tools to Prevent Coronavirus Disease 19 (COVID-19) Transmission. A fundamental concern for the Indonesian State if it cannot immediately overcome the negative impact of COVID-19 transmission is the disruption of several crucial aspects of the country such as health, economy, politics, education, law, defense, and even religion. Therefore, an active role of the community is necessary for assisting the government with attempts to prevent COVID-19 transmission by adhering to the existing COVID-19 protocol hygiene policy.

Research conducted by researchers from McMaster University in Ontario, Canada, about a meta-analysis of 44 studies involving 25,000 people or participants in 16 countries. Results, the highest chance to get infected by coronavirus if we wear a face mask is only 3 percent. Meanwhile, if not using a mask, we have a 17 percent chance of transmitting it (Chu et al., 2020). The use of a new mask will be effacacious if combined with other actions, such as keeping a distance, frequent hand washing, and avoiding touching the face (MacIntyre \& Wang, 2020). Other countries that have managed to maintain the low death rate of COVID-19 below 1 in 1,000,000 through a health protocol policy by using masks are Hong Kong, Japan, Thailand, Taiwan, Vietnam, and Slovakia (Leffler, Ing, McKeown, Pratt, \& Grzybowski, 2020).

Based on the description above, a harmonization and cooperative nature of the community in the prevention is necessary for handling COVID-19. Therefore, this research will focus on the level of public compliance with the COVID-19 protocol 
hygiene policy, especially in Klaten Regency, Central Java-Indonesia. This research is focused in Klaten Regency because it is between the regions with the "red zone" category, namely Solo City and Yogyakarta Province (Priyanto, 2020). The red zone is usually embedded in areas or areas that have too high COVID-19 cases or areas considered as the COVID-19 epicenter. The location of the Klaten Regency flanked by 2 (two) areas of the red zone, makes the Klaten Regency a high-risk area and has the potential to be exposed to COVID-19 transmission. So, the contribution of this research will examine community compliance in Klaten Regency with health protocol policy in Indonesia as an effort to overcome COVID-19. This research is important to carry out to support public literacy regarding prevention efforts in transmitting COVID-19 disease and contribute to the literature on the COVID-19 pandemic in Indonesia.

\section{METHOD}

The research method used is the socio-legal research method, which is a study using a legal science approach (statute approach) and a social science approach (sociological approach) (Benuf \& Azhar, 2020). Socio-legal research which includes non-doctrinal research, according to Nabitatus Sa'adah, this non-doctrinal research is placing the results of social reality observations to be placed as general or primary propositions (Sa'adah, 2018). The data used are secondary data and primary data. Secondary data is data obtained through library studies, while primary data is the data collected directly from the community (people) of Klaten Regency. The primary data in this study include the identity of respondents, knowledge of COVID-19, and behavior in the COVID-19 protocol hygiene. In this research, primary data were obtained by online questionnaires through Google Form distributed through various social media such as Line, Whats App, Facebook, and Twitter.

The specification of the research carried out is quantitative descriptive research, where data obtained from a sample of the study population are analyzed by the statistical methods used and then interpreted. The research population in this study is the entire community of Klaten Regency, using a simple random sampling technique. Sampling was done randomly that every unit of the resident has the same opportunity of being sampled. Determination of the sample size uses the Lameshow's formula because the exact number of Klaten Regency residents is currently unknown precisely. The number of subjects we used was 178 respondents, where the number met the minimum sample size requirement of 96 respondents. Here is the Lameshow's formula:

$$
n=\frac{Z_{1-\frac{a}{2}}^{2} P(1-P)}{d^{2}}
$$

Information:

$\mathrm{n} \quad$ : Number of samples studied 


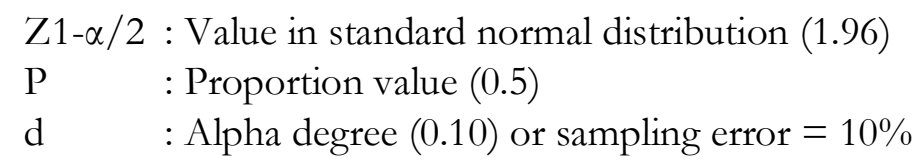

Data analysis conducted from the results of the online questionnaire was processed through statistical tests. The community participation level in this study was calculated by scoring, namely the grading or relative scores of each question variable related to community participation in the implementation of the COVID-19 protocol hygiene policy, the total score of the respondents for further classification. Classification of the scoring results is intended to determine the respondent classifications included in the category of the low, medium, and high level.

\section{RESULTS AND DISCUSSION}

Policy on Prevention of COVID-19 Transmission through the COVID-19 Protocol Hygiene

Based on Presidential Decree No. 11 of 2020, COVID-19 has established as a type of disease that causes a Public Health Emergency. Therefore, preventive attempts must be made from existing provisions. There are several policies adopted by the Government of Indonesia in overcoming COVID-19 that spreads rapidly. Among them is the health quarantine policy of an area as regulated in Law Number 6 of 2018 on Health Quarantine. The implementation of health quarantine is a joint responsibility of the Central Government and Regional Governments as a form of public health protection from diseases either/both public health risk factors that have the potential to cause public health emergencies. Health quarantine is carried out through disease observations and public health risk factors within the transportation, people, goods, eitger/both the environment, as well as responses to public health emergencies in the form of Health quarantine actions. One of the acts of health quarantine is in the form of Large-Scale Social Restrictions (PSBB).

PSBB is regulated under the Government Regulation No. 21 of 2020 concerning Large-Scale Social Restrictions in the Framework of Accelerating Handling of Corona Virus Disease 2019 (COVID-19) (PP No. 21 of 2022). Article 1 PP No. 21 of 2020 states that Large-scale Social Restrictions (PSBB) are restrictions on certain activities of residents in an area suspected of being infected (COVID-19) in such a way as to prevent the possible spread of COVID-19. Large-scale Social Restrictions (PSBB) in the provisions of PP No. 21 in 2020 must meet the criteria of the number of cases either/both the number of deaths due to disease increased and spread significantly and quickly to several regions, and there are epidemiological links with similar events in other districts or countries. Large-scale Social Restrictions (PSBB) at least include activities at school and workplace; restrictions on religious matters; either/both restrictions on activities at public places or facilities. PP No. 21 of 2020 also regulates the implementation of PSBB established by the Minister of Health and can be carried out by the Government of Dacrah based on the approval of the Minister of Health. 
Another government policy in overcoming COVID-19 is to issue health protocols for the community. This protocol is known as the COVID-19 hygiene protocols, one of which relates to the obligation to wear masks for all citizens who are doing activities outside the house and the Hand Washing with Soap (CPTS) movement with running water either/both antiseptic hand sanitizer. This policy is regulated under the Ministry of Health Circular Number HK.02.02 / I / 385/2020 concerning the Use of Masks and the Provision of Hand Washing with Soap (CPTS) Tools to Prevent Coronavirus Disease 19 (COVID-19) Transmission (Handbill of Ministry of Health No. HK.02.02/I/385/2020).

Based on the Ministry of Health Handbill No. HK.02.02/I/385/2020, socialization and communication attempts are necessary for local governments and related parties, related to the use of masks and clean lifestyles by washing hands with soap with running water either/both using antiseptic hand sanitizer after completing an activity. Socialization and education atempts following the Ministry of Health Handbill No. HK.02.02/I/385/2020 should be implemented at public places or facilities such as:

1. Health facilities;

2. Markets and shopping centers;

3. Restaurants and other similar businesses;

4. Land, sea, air and train transportation facilities;

5. Train stations, bus stops, ports and airports; and

6. Other public places and facilities.

\section{Community Compliance with COVID-19 Hygiene Protocol Policy in Klaten Regency-Central Java}

The research outcomes conducted in Klaten District show the characteristics of respondents as Klaten District community. The characteristics of these respondents can be seen in Table 1.

Table 1. Characteristics of Respondents

\begin{tabular}{llcc}
\hline No. & Characteristics & $\begin{array}{c}\text { N (Number of } \\
\text { Respondents) }\end{array}$ & Percentage \\
\hline 1 & Gender & & \\
& Male & 55 & $30,9 \%$ \\
& Female & 123 & $69,1 \%$ \\
\hline
\end{tabular}




\begin{tabular}{|c|c|c|c|}
\hline \multirow[t]{6}{*}{2} & Age & & \\
\hline & $<15$ years old & 8 & $4,49 \%$ \\
\hline & $15-20$ years old & 84 & $47,19 \%$ \\
\hline & $21-25$ years old & 54 & $30,34 \%$ \\
\hline & 25-30 years old & 19 & $10,67 \%$ \\
\hline & $>30$ years old & 13 & $7,3 \%$ \\
\hline \multirow[t]{9}{*}{3} & Profession College Students & & \\
\hline & (Mahasiswa) Civil Servants & 103 & $57,87 \%$ \\
\hline & $(P N S) /$ retired & 9 & $5,06 \%$ \\
\hline & $(T N I) /$ Police & 3 & $1,69 \%$ \\
\hline & Employees Enterpreneur & 11 & $6,18 \%$ \\
\hline & Labor (Burub) Unemployed & 15 & $8,43 \%$ \\
\hline & Others & 27 & $15,17 \%$ \\
\hline & & 10 & $5,62 \%$ \\
\hline & & 0 & $0 \%$ \\
\hline
\end{tabular}

Based on the research outcomes on 178 respondents, data obtained has shown that most of the respondents were female with the number of 123 respondents $(69.1 \%)$, age group of $15-20$ years with the number of 84 respondents $(47.19 \%)$, and college students students (mahasiswa) in the amount of 103 respondents (57.87\%).

Knowledge of cognition is a highly prominent domain in shaping someone's actions (overt behavior). Knowledge can be a cause or motive for someone to behave, so that it can also be the basis for the formation of an action. The parameter of knowledge is decent if the respondent is able to answer $\geq 75 \%$ of the questions correctly, adequate if they are able to answer $56-75 \%$ of the questions correctly, and inadequate if they are able to answer $\leq 55 \%$ of the questions correctly (Notoatmodjo, 2010). The respondent's knowledge measurement level can be seen in Table 2 .

Table 2. Distribution of Respondents by Knowledge Level

\begin{tabular}{clcc}
\hline $\begin{array}{c}\text { No. } \\
\text { Knowledge } \\
\text { level }\end{array}$ & $\begin{array}{l}\text { N (Number of } \\
\text { Respondents) }\end{array}$ & Percentage \\
\hline 1 & Good & 166 & $93,26 \%$ \\
\hline 2 & Enough & 10 & $5,62 \%$ \\
\hline 3 & Less & 2 & $1,12 \%$ \\
\hline
\end{tabular}

The research outcomes show that as many as 166 respondents $(82.75 \%)$ had a decent level of knowledge about COVID-19 matters. Regarding questions about the 
causes of COVID-19, 97.75\% of respondents correnctly answered that the cause of COVID-19 is a virus. COVID-19 is caused by Severe Acute Respiratory Coronavirus2 (SARS-CoV-2) (Heymann \& Shindo, 2020). Regarding common symptoms of COVID-19, 100\% of respondents answered correctly that the symptoms are dry cough, high fever, and shortness of breath. Manifestations of COVID-19 can heal but can also cause death (Guan et al., 2020), which $92 \%$ of respondents answered correctly. The fact that COVID-19 can be transmitted to others answered correctly by $100 \%$ of respondents. $78 \%$ of respondents answered correctly that transmission can happen through patient droplets (Liu et al., 2020). Moreover, 85\% respondents answered correctly that vaccines have not yet found (Ahmed, Quadeer, \& McKay, 2020). Last, regarding how to prevent transmission, $98 \%$ of respondents answered correctly to wit maintaining personal hygiene, washing hands with soap/using hand sanitizer, keeping physical distance, using a mask while traveling, and spraying disinfectants on frequently touched objects (Guan et al., 2020).

Maintaining hygiene is a preventive health action that focuses its activities on individual health efforts. Hygiene matters can also relate to health problems, as well as various behaviors that can improve hygienic lifestyle that leads to good health. Participation parameter measurement can be seen in Table 3 .

Table 3. The Level of Community Participation in COVID-19 Protocol Hygiene

\begin{tabular}{clcc}
\hline No. & Hygiene Indicator & $\begin{array}{c}\text { N (Number of } \\
\text { Respondents) }\end{array}$ & Percentage \\
\hline 1 & $\begin{array}{l}\text { Wash Hands With } \\
\text { Soap }\end{array}$ & 157 & $88,2 \%$ \\
\hline 2 & $\begin{array}{l}\text { The use of masks } \\
\text { when traveling }\end{array}$ & 133 & $74,72 \%$ \\
\hline 3 & Use of Handsanitizer & 123 & $69,1 \%$ \\
\hline 4 & Stay at home & 56 & $31,46 \%$ \\
\hline 5 & $\begin{array}{l}\text { Availability of Public } \\
\text { Handwashing } \\
\text { Facilities }\end{array}$ & 140 & $78,65 \%$ \\
\hline
\end{tabular}

Based on the research outcomes, the highest level of community participation is in washing hands using soap, which is $88.2 \%$. The amount of Klaten community participation in the practice of washing hands using soap has highly contributed to the prevention of COVID-19 transmission in Klaten. Hand washing using soap is one of the effective steps in suppressing the spread of COVID-19. We need to wash our hands with soap and running water for at least 20 seconds (Aluga, 2020).

The coverage of "stay at home" behavior shows the least participation rate, which is $31.46 \%$. Many citizens in Klaten still do activities outside the house even 
though not only going to work and buying necessities, but not a few of them are also hanging out or visiting friends and relatives. This will surely increase the potential spread of COVID-19. The practice of maintaining physical space between people within a minimum distance of 6 feet away will minimize the spread of COVID-19 (Centers for Disease Control and Prevention, 2020). Wearing masks while traveling can also narrow the transmission of COVID-19. The application of masks is helpful to prevent disease not to infect healthy people and prevent transmission without symptoms. The use of face masks by public in general has a high potential value in limiting transmission as well as the burden of pandemics in the community. It is more beneficial when the accustom of wearing face masks is used in conjunction with other social distancing practices (Eikenberry et al., 2020).

From the aspect of health protocol, the Government of Indonesia through the Ministry of Health has been quite well in issuing a policy to accelerate COVID-19 countermeasures, in which the government sets a temperature of $38^{\circ} \mathrm{C}$ as a point of fever that has potential to COVID-19 infection. Therefore, health protocol existence as a government policy in accelerating COVID-19 countermeasures is expected by parties such as the Regional Government and the community to play an active role in referring those who have a high-temperature fever to the nearest hospital. Then, the Local Government can socialize or urge people to wear masks. For emergencies, if you sneeze or cough in a public area, it is recommended cover your mouth with your inner elbows or upper sleeve. People who feel sick are also advised not to use public transportation to minimize the possible risk of spreading the disease.

If the criteria of suspected COVID-19 infection (high fever, flu, cough), they will be referred to one of the COVID-19 referral hospitals and treated in an isolation room (MBN Wajdi, I Kuswandi, \& U Al Faruq, 2020). If it does not meet the criteria, treatment will adjust to the referral of the examining doctor. Related to inspection in the area, the government applies the same method by taking specimens of suspect COVID-19 and sent directly to the Center for Health Research and Development to find out the suspect's status. The government declares a patient negative for COVID19 after going through 2 stages of examination. If not, according to the procedure, health will continue to be treated in an isolated area.

\section{CONCLUSION}

The Government of Indonesia has established COVID-19 as a type of disease that causes a Public Health Emergency. Therefore, preventive attempts must be made following existing provisions. The policy currently applied is health quarantine. One of the acts of health quarantine is in the form of Large-Scale Social Restrictions (PSBB). PSBB is regulated under the Government Regulation No. 21 of 2020 concerning Large-Scale Social Restrictions in the Framework of Accelerating Handling of Corona Virus Disease 2019. Another policy is the issuance of health protocols for the community. This protocol is known as the COVID-19 hygiene protocol, one of 
which is related to the obligation for all citizens to wear masks outside the house and the Hand Washing with Soap (CPTS) movement with running water either/both the use of antiseptic hand sanitizers. This policy is contained under the Ministry of Health Circular Number HK.02.02/I/385/2020. Therefore, health protocol existance as a government policy in accelerating COVID-19 countermeasures is expected by parties such as the Regional Government and the community to play an active role in referring those who are feverish to the nearest hospital. Then, the Regional Government can socialize or urge people to wear masks. For emergencies, if you sneeze or cough in a public area, it is recommended to cover your mouth with your inner elbows or upper sleeve. People who are sick are also advised not to use public transportation to minimize the possible risk of spreading the disease.

Related to the existence of the COVID-19 hygiene protocol, the level of awareness and compliance with the policy is highly necessary among the public. In Klaten, Central Java, the level of compliance awareness of the adverse effects of COVID-19 is exceptionally well. Public compliance with health protocols in the use of masks and washing hands with soap in running water either/both using antiseptic hand sanitizers also shows a good percentage. A decent level of awareness and compliance within the community can help the government in accelerating the response to the spread of COVID-19.

\section{REFERENCES}

Ahmed, S. F., Quadeer, A. A., \& McKay, M. R. (2020). Preliminary Identification of Potential Vaccine Targets for the COVID-19 Coronavirus (SARS-CoV-2)

Based on SARS-CoV Immunological Studies. Viruses, 12(3), 254. https://doi.org/10.3390/v12030254

Al-Fatih, S., Ahsany, F., \& Alamsyah, A. F. (2020). Legal Protection of Labor Rights During the Coronavirus Disease 2019 (Covid-19) Pandemic. Jurnal Pembabaruan Hukum, 7(2), 100-115. https://doi.org/10.26532/jph.v7i2.10975

Aluga, M. A. (2020). Coronavirus Disease 2019 (COVID-19) in Kenya: Preparedness, response and transmissibility. Journal of Microbiology, Immunology and Infection. https://doi.org/10.1016/j.jmii.2020.04.011

Barkur, G., Vibha, \& Kamath, G. B. (2020). Sentiment analysis of nationwide lockdown due to COVID 19 outbreak: Evidence from India. Asian Journal of Psychiatry, 51, 102089. https://doi.org/10.1016/j.ajp.2020.102089

Bashir, M. F., Ma, B., Bilal, Komal, B., Bashir, M. A., Tan, D., \& Bashir, M. (2020). Correlation between climate indicators and COVID-19 pandemic in New York, USA. Science of The Total Environment, 728, 138835. https://doi.org/10.1016/j.scitotenv.2020.138835

Benuf, K., \& Azhar, M. (2020). Metodologi Penelitian Hukum sebagai Instrumen Mengurai Permasalahan Hukum Kontemporer. Gema Keadilan, 7(1), 20-33. 
https://doi.org/https://doi.org/10.14710/gk.7.1.20-33

Centers for Disease Control and Prevention. (2020). Transmission of Coronavirus Disease 2019 (COVID-19).

Chakraborty, I., \& Maity, P. (2020). COVID-19 outbreak: Migration, effects on society, global environment and prevention. Science of The Total Environment, 728 , 138882. https://doi.org/10.1016/j.scitotenv.2020.138882

Chen, N., Zhou, M., Dong, X., Qu, J., Gong, F., Han, Y., ... Zhang, L. (2020). Epidemiological and clinical characteristics of 99 cases of 2019 novel coronavirus pneumonia in Wuhan, China: a descriptive study. The Lancet, 395(10223), 507-513. https://doi.org/10.1016/S0140-6736(20)30211-7

Chu, D. K., Akl, E. A., Duda, S., Solo, K., Yaacoub, S., Schünemann, H. J., .. Schünemann, H. J. (2020). Physical distancing, face masks, and eye protection to prevent person-to-person transmission of SARS-CoV-2 and COVID-19: a systematic review and meta-analysis. The Lancet, 395(10242), 1973-1987. https://doi.org/10.1016/S0140-6736(20)31142-9

Dantas, G., Siciliano, B., França, B. B., da Silva, C. M., \& Arbilla, G. (2020). The impact of COVID-19 partial lockdown on the air quality of the city of Rio de Janeiro, Brazil. Science of The Total Environment, 729, 139085. https://doi.org/10.1016/j.scitotenv.2020.139085

Eikenberry, S. E., Mancuso, M., Iboi, E., Phan, T., Eikenberry, K., Kuang, Y., ... Gumel, A. B. (2020). To mask or not to mask: Modeling the potential for face mask use by the general public to curtail the COVID-19 pandemic. Infectious Disease Modelling, 5, 293-308. https://doi.org/10.1016/j.idm.2020.04.001

Guan, W., Ni, Z., Hu, Y., Liang, W., Ou, C., He, J., ... Zhong, N. (2020). Clinical Characteristics of Coronavirus Disease 2019 in China. New England Journal of Medicine, 382(18), 1708-1720. https://doi.org/10.1056/NEJMoa2002032

Heymann, D. L., \& Shindo, N. (2020). COVID-19: what is next for public health? The Lancet, 395(10224), 542-545. https://doi.org/10.1016/S01406736(20)30374-3

Hidayatullah, S. (2016). Kewenangan Negara dan Kewajiban Subyek Hukum Perdata dalam Hubungannya dengan Hukum Pajak. Pranata Hukum, 11(1), 1-8. https://doi.org/doi.org/10.36448/pranatahukum.v11i1.189

Ina Ola, C. Y., Huda, K., \& Putera, A. P. (2018). Tanggung Jawab Pidana, Perdata Dan Administrasi Asisten Perawat Dalam Pelayanan Kesehatan Desa Swadaya. Jurnal Ilmiah Hukum LEG ALITY, 25(2), 134-146. https://doi.org/10.22219/jihl.v25i2.5997

Kementrian Kesehatan Republik Indonesia. (2020). Situasi Terkini Perkembangan Coronavirus Disease (COVID-19) 6 Mei 2020.

Leffler, C., Ing, E., McKeown, C., Pratt, D., \& Grzybowski, A. (2020). Country-wide Mortality from the Novel Coronavirus (COVID-19) Pandemic and Notes Regarding Mask Usage by the Public. Technical Report. 
https:// doi.org/10.13140/RG.2.2.36006.27200

Liu, J., Liao, X., Qian, S., Yuan, J., Wang, F., Liu, Y., ... Zhang, Z. (2020).

Community Transmission of Severe Acute Respiratory Syndrome Coronavirus

2, Shenzhen, China, 2020. Emerging Infectious Diseases, 26(6).

https://doi.org/10.3201/eid2606.200239

Lupia, T., Scabini, S., Mornese Pinna, S., Di Perri, G., De Rosa, F. G., \& Corcione, S. (2020). 2019 novel coronavirus (2019-nCoV) outbreak: A new challenge. Journal of Global Antimicrobial Resistance, 21, 22-27. https://doi.org/10.1016/j.jgar.2020.02.021

MacIntyre, C. R., \& Wang, Q. (2020). Physical distancing, face masks, and eye protection for prevention of COVID-19. The Lancet, 395(10242), 1950-1951. https://doi.org/10.1016/S0140-6736(20)31183-1

MBN Wajdi, I Kuswandi, \& U Al Faruq. (2020). Education Policy Overcome Coronavirus, A Study of Indonesians. EDUTEC: Journal of Education and Technology, 3(2), 102. Retrieved from http:// ejournal.ijshs.org/index.php/edu/article/download/42/31

Notoatmodjo, S. (2010). Metodologi Penelitian Kesehatan. Jakarta: Rineka Cipta.

Priyanto, M. A. (2020). Kabupaten dan Kota Ini Masuk Zona Merah Virus Corona di Jateng.

Sa'adah, N. (2018). Kebijakan Pengampunan Pajak (Tax Amnesty) Berdasarkan Keadilan Yang Mendukung Iklim Investasi Indonesia. Masalab-Masalab Hukum, 46(2), 182-189. https://doi.org/10.14710/mmh.46.2.2017.182-189

Shereen, M. A., Khan, S., Kazmi, A., Bashir, N., \& Siddique, R. (2020). COVID-19 infection: Origin, transmission, and characteristics of human coronaviruses. Journal of Advanced Research, 24, 91-98. https://doi.org/10.1016/j.jare.2020.03.005

Syah, R. H. (2020). Dampak Covid-19 pada Pendidikan di Indonesia: Sekolah, Keterampilan, dan Proses Pembelajaran. SALAM: Jurnal Sosial Dan Budaya SyarI, 7(5), 395-402. https://doi.org/10.15408/sjsbs.v7i5.15314

World Health Organization. (2020). Novel Coronavirus (2019-nCoV) Situation Repost-51.

Xie, M., \& Chen, Q. (2020). Insight into 2019 novel coronavirus - An updated interim review and lessons from SARS-CoV and MERS-CoV. International Journal of Infectious Diseases, 94, 119-124. https://doi.org/10.1016/j.ijid.2020.03.071

Xu, B., Gutierrez, B., Mekaru, S., Sewalk, K., Goodwin, L., Loskill, A., ... Kraemer, M. U. G. (2020). Epidemiological data from the COVID-19 outbreak, real-time case information. Scientific Data, 7(1), 1-6. https://doi.org/10.1038/s41597-0200448-0

Yunus, N. R. (2020). Kebijakan Covid-19, Bebaskan Narapidana dan Pidanakan 
Pelanggar PSBB. 'Adalah: Buletin Hukum \& Keadilan, 4(1), 1-6. https://doi.org/10.15408/adalah.v4i1.15262

Yunus, N. R., \& Rezki, A. (2020). Kebijakan Pemberlakuan Lock Down Sebagai Antisipasi Penyebaran Corona Virus Covid-19. SALAM: Jurnal Sosial Dan Budaya Syar-I, 7(3), 227-238. https://doi.org/10.15408/sjsbs.v7i3.15083 